\title{
Arming the other half: attaining sustainability through women with microfinance
}

\author{
F. Tariq ${ }^{1} \&$ S. Umar ${ }^{2}$ \\ ${ }^{1}$ North Carolina State University, USA \\ ${ }^{2}$ Local Government and Community Development Department, Pakistan
}

\begin{abstract}
Traditional approaches have repeatedly failed in the past to gain successful sustainable development even after allocating huge development funds. Projects cannot be solved without taking into account women's concerns and realities. This should not come as a surprise since women constitute half of society and ignoring this reality cannot solve any human problem. Governments and the international community have consensus that women play a key role in all successful development processes. This paper builds on the premise that sustainable development and women's empowerment can be realized through microfinance. In order to be effective, sustainable development must go hand in hand with women-focused microfinance policies. The recommendations are based on the Islamic finance system and the experiences of low-income women with housing microfinance practices in Pakistan.
\end{abstract}

Keywords: sustainable development, women empowerment, Islamic microfinance, housing microfinance.

\section{Sustainability and women}

To boost sustainable development, the United Nations announced the Millennium Development Goals, aimed at achieving them by the year 2015 [4]. As argued by Easterly [5], sustainable development is a complex process and cannot be 'programmed' through linear interventions. Brundtland's [6] concept of sustainable development is "development that meets the needs of the present without compromising the ability of future generations to meet their own needs". In Nordberg's words, "sustainability is a concept increasingly used as a measure of the worth of an approach to meeting shelter needs" [7]. Many studies reveal 
that poor people build and improve houses incrementally as needs arise. "Incrementalism is a method of adding to a project many small (often unplanned), incremental changes instead of a few (extensively planned) large jumps" NHP [18]. "For individuals or households with limited incomes, the only possibility of home ownership (even in an illegal settlement), is through shelter investment made in several stages, all made at separate times" Ferguson and Navarrete [19]. Abrams states that incremental building demands incremental financing [20]. According to Smets [21], a microloan with a maturity period of 5 years or less can enable flexibility, as labor and materials are added incrementally for construction or improvement over a period of years.

As illustrated in Figure 1 (based on Seelos and Mair [5]), the supply of microfinance services and products satisfies basic human needs and creates communities that establish collaborative behavior as a prerequisite for participating in social and economic development. Further, it translates needs of future generations into action today at different levels of achieved sustainable development.

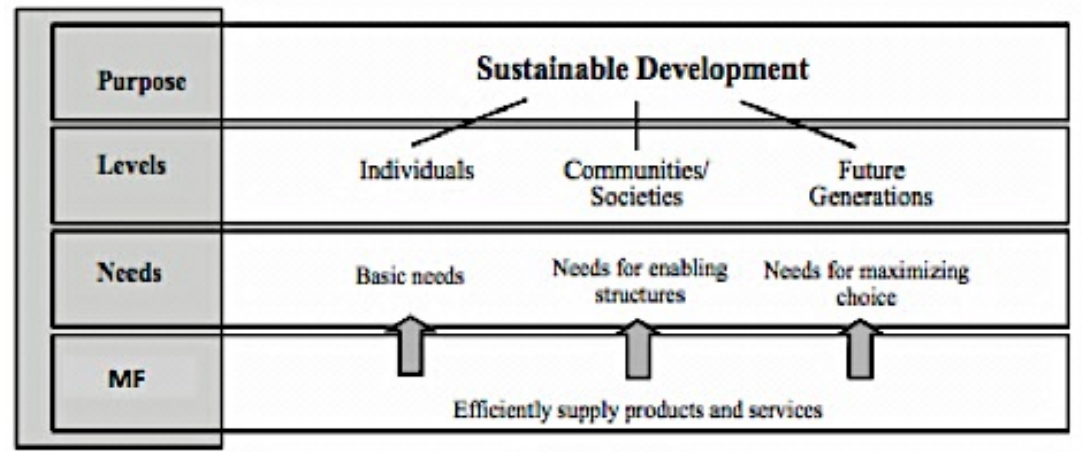

Figure 1: Contribution of microfinance to sustainable development.

The 2003 Johannesburg Declaration on sustainable development states, "women's empowerment, emancipation and gender equality are integrated in all the activities" of sustainable development [6]. Microfinance comes as a form of financial solution that has as its primary aims empowerment of women and the combating of poverty. According to the United Nations, microcredit programs have tripled within the past five years and nearly twenty-seven million people, mostly women, became borrowers by 2001 [7]. Over the past 30 years, microfinance practitioners and policy makers have gravitated towards the view that targeting women in microcredit programs is the most effective means to deliver wider social benefits. Indeed, there exists a large body of evidence which shows that women are more likely than men to spend resources in ways that benefit the entire household [8-10], increasing resources in the hands of female household members has a greater impact on family welfare and at large on community welfare $[11,12]$. 


\section{Housing microfinance and women}

The majority of microfinance programs tend to explicitly empower women. However, the means vary. Some programs highlight women as among the poorest populations and in most circumstances underprivileged. Other programs argue that investment in women's human potential enables them to consider options in economic development and growth. Evidence from the literature shows that the wellbeing of families, especially of children is affected positively by an increase in women's resources [13]. Finally, the majority of microfinance institutions prefer women as members, because of their reputation for being reliable borrowers, thereby contributing to their financial viability [14].

An impact assessment of the SEWA Bank's slum-upgrading program that included 3,700 progressive housing loans to women reported increases in literacy (school enrolment), productivity (an increase in the number of working hours), income and health (lower incidence of illness and thus lower health expenditure); and also increased marriage opportunities, higher status and greater respect in the community for women [15].

\section{Microfinance under Islamic finance}

Contrary to modern financing procedures, the concept of Islamic financing prohibits interest [16, 17. More than $95 \%$ of the population of Pakistan is Muslim and a country that adopting Islamic finance practices. As a result, Islamic financing is growing rapidly to the point where this philosophy accounts for $3.8 \%$ of total deposits in the banking sector of Pakistan [18]. Microfinance strategies adopted by Pakistani Banks are a quite new movement. After the promulgation of ordinance in 2001, six Microfinance Banks and many NGOs boosted microfinance practices. Microfinance reached three million customers in 2010. Ahmed investigated similarities between microfinance and Islamic finance systems and found that both forms of financing focus on helping the poor and that capital is provided to small investors without discrimination. Second, Islamic finance is based on achievement of social goals and development; likewise, microfinance also contributes towards social development by helping the poor and small investors [19].

The teachings of Islam encourage Muslims to give donations in the form of Sadqa, Ushar, and Zakat to the poor. Zakat is compulsory for every rich Muslim to give 2.5 percent of total wealth to the poor [18]. In Islamic microfinance, wealthy Muslims, through donations, contribute funds for micro-loans considered as an act of worship [19].

The Islamic microfinance practiced by the Pakistani NGO-Akhuwat is guided by Islamic strategies for disbursing loans, for example by marketing and disbursing them in mosques, which are considered as Muslim sacred religious places. Each NGO branch is located within or just outside the mosque's premises. Introduction to the program is also given after prayers when people have congregated there. Hence people assume that the NGO is sincere enough 
and is not lying in a holy place [9]. Secondly, the loan amount is interest free, which is appreciated by the majority of Muslims.

\section{Microfinance and women in Pakistan}

The status of Islamic women varies in different Muslim countries, which interpret Islamic religion and law differently. The doctrine of Islam that came from the revelations to Muhammad (PBUH), the Prophet about 610 C.E. was sympathetic toward women and concerned about their equal treatment. The family and the woman's role in Muslim societies have been affected by various social, economic and financial factors including increases in technological development and urbanization. In most Islamic countries, like Pakistan, people cannot afford to confine women to do only household work. Additional work is required to support the family [20]. For a woman, apart from financial and economic functions, a house may also serve a specific cultural purpose. For example, the house of an extended Muslim family practicing pardah requires a separate space for female family members. Moreover, female members require adequate housing because they often combine roles of regeneration, income generation, and physical management of the house itself [15].

Home ownership and accessing finance is particularly difficult for women, who typically do not own land and other property to use as collateral. According to UNICEF's 2007 report, research on Pakistani women revealed that they owned less than three percent of the housing plots surveyed, even though Islamic law clearly entitles women to inherit land and property [21]. According to Hussein and Plateau [22], male clients have 3.5 times more access to financial services then female borrowers in the rural area of Pakistan. The average size of loans allocated to the women was Rs. (Pak) 8050 while the average for male clients was Rs. (Pak) 19382.

Also, women in Pakistan face a mobility barrier, which includes travel for business purposes, not only as a result of poor infrastructure but also due to the social and cultural norms that still discourage women from going outside and moving freely in the community. This limited mobility often restricts their choice of business, with the result that most women engage in businesses that do not require mobility and which also, typically, only require contact with other women, for example, beauty salons [23].

Microfinance may seem like an obvious solution. Indeed, microfinance institutions are providing women with collateral-free loans and simplified application procedures to encourage them to develop economies and to pursue enterprise to overcome economic and social barriers [24]. According to a 2005 report by the United Nation's Convention on the "Elimination of All Forms of Discrimination against Women," in Pakistan, the number of self-employed women has increased from 11.7 percent in 1997-1998 to 15.7 percent in 20012002. New Pakistani government policy is emphasizing loans to women and as a result during 2006-07, micro credit loans to women reached a record number of 266,495. More than half $(54 \%)$ of active borrowers are now female (Figure 2) [25]. 


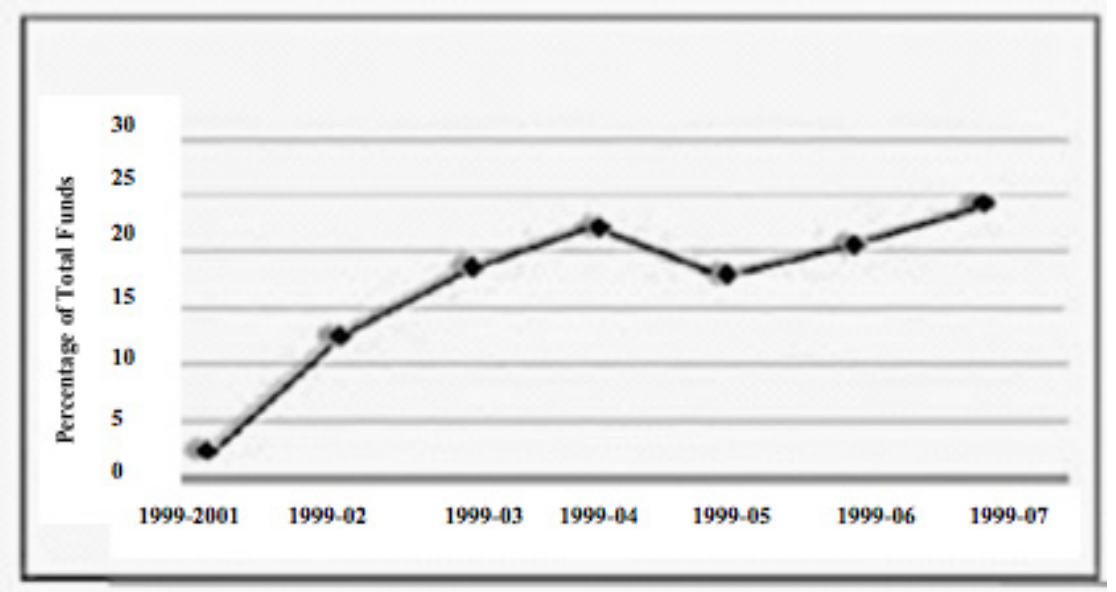

Figure 2: $\quad$ Growth in credit portfolio by women (1999-2007).

\section{Evidence of Islamic housing microfinance practiced by Pakistani women}

To gather local data about housing microfinance practices in Pakistan, women engaged in incremental house construction with and without microfinance were interviewed in 2011 as part of a field study of microfinancing linked to incremental housing development. Subjects $(\mathrm{N}=40)$ were selected from the urban neighbourhoods of Lahore and the loan portfolio of NGO-Akhuwat (Islamic housing microfinance institution). The questions relating to the participant's experience with housing microfinance and incremental housing process were asked. It was evident from the interviews that housing microfinance makes up a noteworthy bridging resource that allows for the necessary financial support to poor women in order to construct their houses incrementally and establish their businesses inside.

Figure 3 shows the result of incremental construction without housing microfinance and without taking the suggestions of women living inside the house into account. In this group, many women spending nearly 10 hours a day in the kitchen complain about the unhygienic conditions, lack of ventilation, and suffocating bad smells.

Figure 4 shows the conversion and use of a guest bedroom as a beauty parlor. The woman running it is paying back both the business and housing micro-loans efficiently.

Figure 5 shows the third phase of construction with housing microfinance. The woman is happy with the construction, including the courtyard left open for air and rain. After the death of her husband, she succeeded in maintaining privacy with the help of housing microfinance. Now she is easily paying the installments that are without interest. 


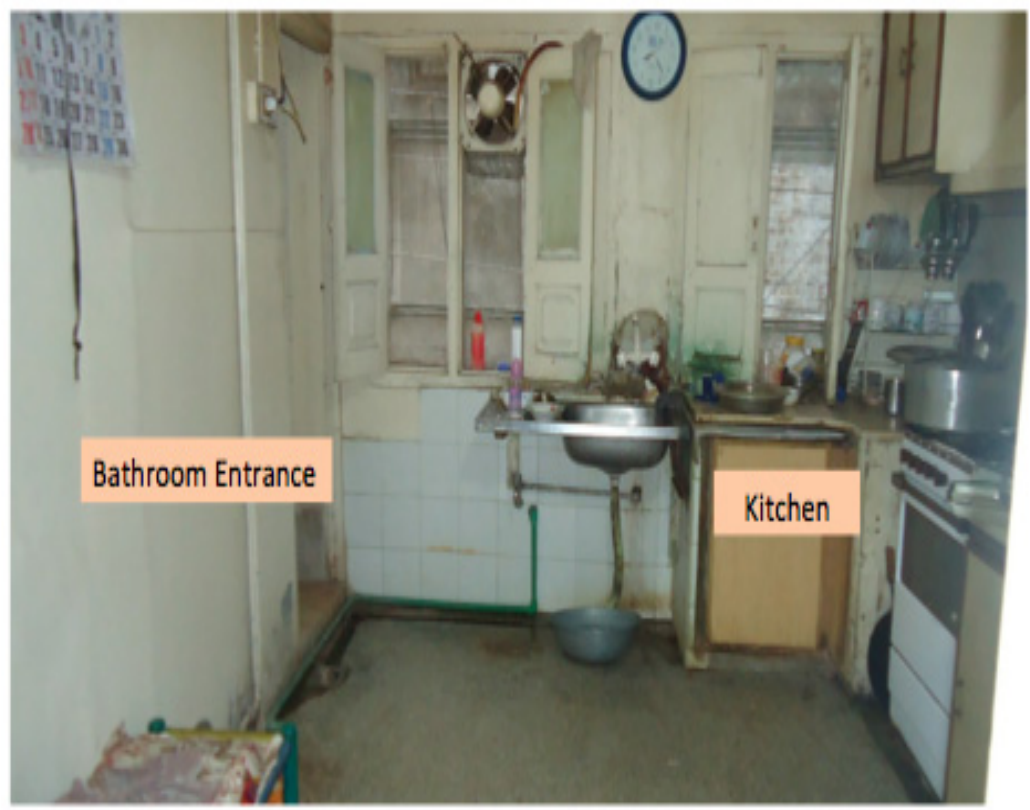

Figure 3: Women face unhygienic conditions while cooking in an unventilated the kitchen.

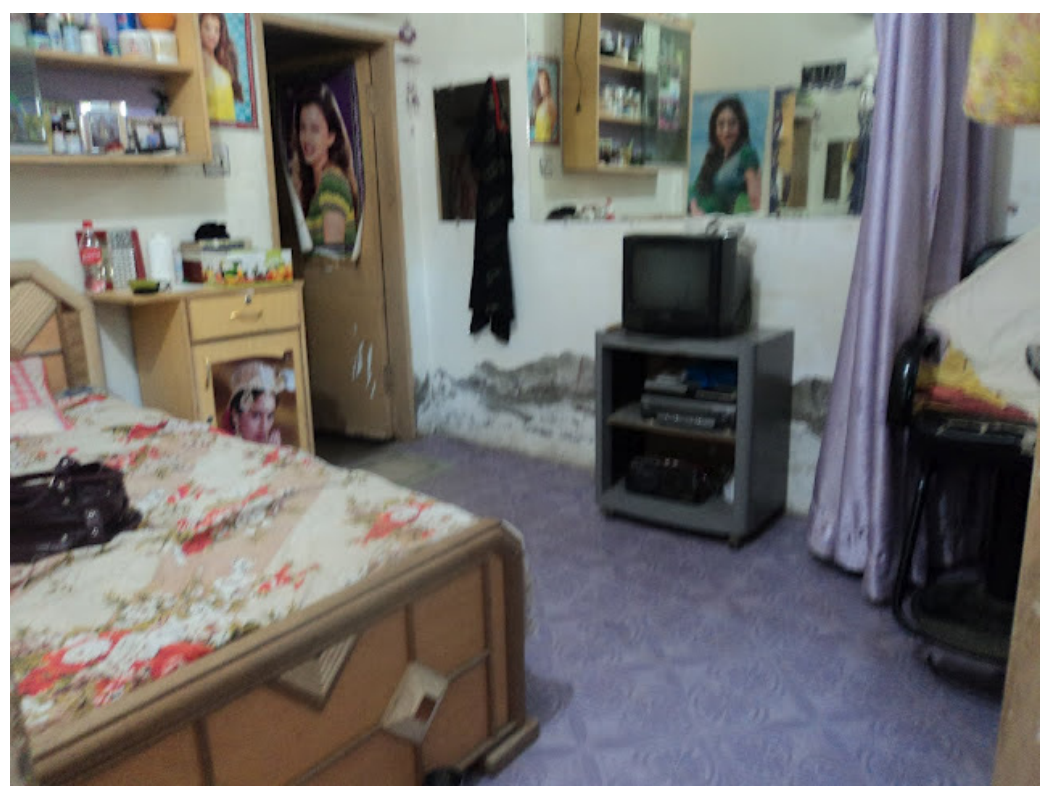

Figure 4: Beauty parlour run by a female household member established within a house with housing microfinance 


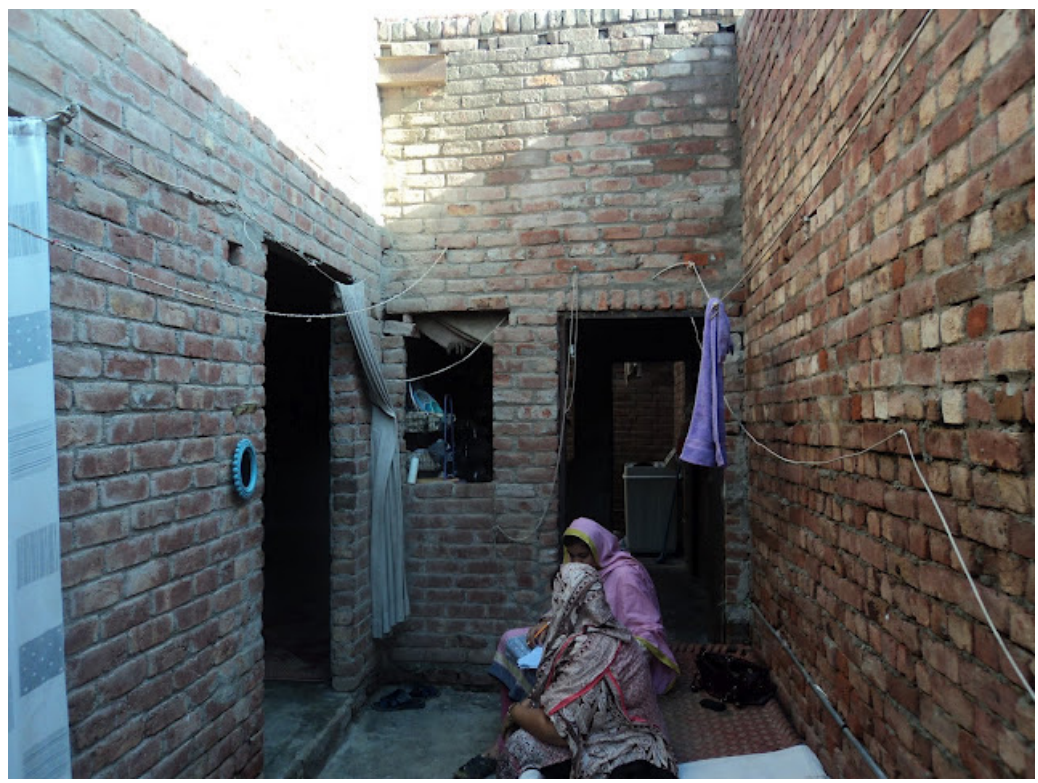

Figure 5: Incremental construction of a house with housing microfinance by a woman

\section{Recommendations}

Pakistan has $48 \%$ female population; consider, if all the women sit at home idle it means half of the population remains idle. The requirement of the day and of the present age is that women should contribute towards sustainable development of their country [26].

Housing microfinance resonates with both Islamic traditions and the fluctuating incomes of poor women. It provides Pakistani women the tools necessary for sustainability, not only for themselves but also for their families and the communities they live in. Houses planned and built according to their specific needs are more productive. The great potential for achieving scale and sustainability can be realized if financial institutions and governments work together [27]. To achieve this end, the Pakistani government should encourage microfinance institutions to adopt a targeted, articulated gender focus as part of the national strategy to address women's empowerment. By providing womenonly credit windows, female staff, and trained personnel adept at serving the banks' female clientele, much can be done to foster a female micro-client base [21]. Also, in the case of housing microfinance, technical skills are required to help create liveable, healthy spaces inside the house. If this can be achieved together with conversion of a working space for microenterprise within the house, concrete steps towards sustainable development will be achieved. 


\section{References}

[1] V. P. Nanda, "Sustainable Development, International Trade and the Doha Agenda for Development," Chap. L. Rev., vol. 8, pp. 53, 2005.

[2] W. Easterly, "The middle class consensus and economic development," Journal of economic growth, vol. 6, no. 4, pp. 317-335, 2001.

[3] G. H. Brundtland, "World commission on environment and development," Our common future, pp. 8-9, 1987.

[4] R. Nordberg, "Building sustainable cities," Habitat Debate, vol. 5, no. 2, 2004.

[5] C. Seelos, and J. Mair, "Social entrepreneurship: Creating new business models to serve the poor," Business horizons, vol. 48, no. 3, pp. 241-246, 2005.

[6] T. M. Parris, "Gender and Sustainable Development," Environment: Science and Policy for Sustainable Development, vol. 47, no. 7, pp. 3-3, 2005.

[7] M. S. Barr, "Microfinance and financial development," University of Michigan Legal Working Paper Series, pp. 46, 2005.

[8] B. Armendáriz, and J. Morduch, "The economics of microfinance," Cambridge, MA: MIT Press, 2005.

[9] S. R. Khandker, "Microfinance and poverty: evidence using panel data from Bangladesh," The World Bank Economic Review, vol. 19, no. 2, pp. 263-286, 2005.

[10] M. M. Pitt, S. R. Khandker, and J. Cartwright, "Empowering women with micro finance: evidence from Bangladesh," Economic Development and Cultural Change, vol. 54, no. 4, pp. 791-831, 2006.

[11] D. Thomas, "Intra-household resource allocation: An inferential approach," Journal of human resources, pp. 635-664, 1990.

[12] T. M. P. Ngo, and Z. Wahhaj, "Microfinance and gender empowerment," Journal of Development Economics, 2011.

[13] A. M. Goetz, and R. S. Gupta, "Who takes the credit? Gender, power, and control over loan use in rural credit programs in Bangladesh," World development, vol. 24, no. 1, pp. 45-63, 1996.

[14] S. M. Hashemi, S. R. Schuler, and A. P. Riley, "Rural credit programs and women's empowerment in Bangladesh," World development, vol. 24, no. 4, pp. 635-653, 1996.

[15] P. Smets, "Small is beautiful, but big is often the practice: Housing microfinance in discussion," Habitat International, vol. 30, no. 3, pp. 595613, 2006.

[16] M. N. Siddiqi, Issues in Islamic banking: The Islamic Foundation, 1983.

[17] F. M. Taib, T. Ramayah, and D. A. Razak, "Factors influencing intention to use diminishing partnership home financing," International Journal of Islamic and Middle Eastern Finance and Management, vol. 1, no. 3, pp. 235-248, 2008. 
[18] M. M. Saeed, T. U. Rehman, and M. Qasim, "Monitoring in Profit and Loss Sharing Model of Islamic Microfinance," Journal of Social Economics, vol. 24, no. 12, pp. 1470-1487, 2002.

[19] H. Ahmed, "Waqf-based microfinance: Realizing the social role of Islamic Finance," World Bank, 2007.

[20] J. A. Sechzer, “"Islam and Woman: Where Tradition Meets Modernity": History and Interpretations of Islamic Women's Status," Sex roles, vol. 51, no. 5, pp. 263-272, 2004.

[21] C. Niethammer, T. Saeed, S. S. Mohamed et al., "Women entrepreneurs and access to finance in Pakistan," Women's Policy Journal, vol. 4, pp. 1$12,2007$.

[22] M. Hussein, and S. Plateau, "Microfinance," Karachi, Pakistan: Oxford University Press, 2006.

[23] M. A. Roomi, and P. Harrison, "Behind the veil: women-only entrepreneurship training in Pakistan," International Journal of Gender and Entrepreneurship, vol. 2, no. 2, pp. 150-172, 2010.

[24] A. R. Morrison, D. Raju, and N. Sinha, Gender equality, poverty and economic growth: World Bank, 2007.

[25] Z. Mustafa, and N. Ismailov, "Entrepreneurship and Microfinance-A tool for empowerment of poor-Case of Akhuwat, Pakistan," 2008.

[26] W. Rehman, "Micro finance: barriers to the microfinance outreach for women in Pakistan," 2007.

[27] M. Malhotra, "Financing her home, one wall at a time," Environment and urbanization, vol. 15, no. 2, pp. 217-228, 2003. 